\title{
Acid tolerance in Rhizobium meliloti strain WSM419 involves a two-component sensor-regulator system
}

\author{
Ravi P. Tiwari, Wayne G. Reeve, Michael J. Dilworth \\ and Andrew R. Glenn
}

Nitrogen Fixation Research Group, School of Biological and Environmental Sciences, Murdoch University,

Murdoch, Western

Australia 6150, Australia

\author{
Author for correspondence: Andrew R. Glenn. Tel: +619360 2231. Fax: +6193606303. \\ e-mail: arglenn@central.murdoch.edu.au
}

\begin{abstract}
An acid-sensitive mutant, TG5-46, derived from Rhizobium meliloti WSM419 by In 5 mutagenesis, fails to grow below pH 6.0 whereas the parent strain grows at pH 5.7. The DNA sequence of a $2 \cdot 2 \mathrm{~kb}$ rhizobial DNA region flanking In 5 in TG5-46 contains two open reading frames, ORF1 (designated act5) and ORF2 (designated actR), having high similarity to the sensor-regulator pairs of the two-component systems involved in signal transduction in prokaryotes. Insertion of an omega interposon into actS in $R$. meliloti WSM419 resulted in an acid-sensitive phenotype. A DNA fragment from the wild-type complemented the acid-sensitive phenotype of RT295 (ActS-) and TG5-46 (ActR-), while fragments containing only actR or actS complemented TG5-46 and RT295, respectively. The presence of multiple copies of actR complemented not only TG5-46 but also RT295. Cloning DNA upstream from actR and actS into a broad-host-range lac $z$ expression vector and measuring $\beta$-galactosidase activities showed that both genes are constitutively expressed regardless of the external pH. Genomic DNA from all strains of $R$. meliloti, but no other bacteria tested, hybridized with an actRS probe at high stringency. These data implicate a two-component sensor-regulator protein pair in acid tolerance in $R$. meliloti and suggest their involvement in pH sensing and/or response by these bacteria.
\end{abstract}

Keywords: Rbizobium meliloti, acid-tolerance genes, two-component sensor-regulator system, pH sensing

\section{INTRODUCTION}

Approximately a quarter of the world's agricultural soils are acidic and there is increasing concern about soil acidification (Munns, 1986). Soil acidity affects the growth and survival of soil bacteria like Rbizobium (Graham \& Parker, 1964) and the nodulation of legumes (Munns, 1986; Penny et al., 1977). This influences the amount of $\mathrm{N}_{2}$ being fixed, and therefore the input of $\mathrm{N}$ into many agricultural systems. In some cases the root nodule bacteria represent the acid-sensitive component of the symbiosis (Robson \& Loneragan, 1970; Munns, 1986); Rbizobium meliloti is especially sensitive to acidity. This raises questions as to how root nodule bacteria respond to acidity and why some, like R. meliloti, are acid-sensitive and others are more acid-tolerant.
Most bacteria that have been studied (Caldwell, 1956; Waddel \& Bates, 1969; Thomas et al., 1976; Padan et al., 1982; Booth, 1985; Padan \& Schuldiner, 1986) maintain a relatively constant internal $\mathrm{pH}\left(\mathrm{pH}_{\mathrm{i}}\right)$ over a wide range of external $\mathrm{pH}\left(\mathrm{pH}_{\mathrm{e}}\right)$. $\mathrm{R}$. meliloti maintains a slightly alkaline $\mathrm{pH}_{\mathrm{i}}$ even when the $\mathrm{pH}_{\mathrm{e}}$ is acidic (O'Hara et al., 1989). This control of $\mathrm{pH}$ presumably involves one or more mechanisms for regulating the influx and efflux of protons across the cytoplasmic membrane (Glenn \& Dilworth, 1994). Little is known about such mechanisms in Rbizobium, whether they are inducible or constitutive, or how the cell 'senses' changes in the $\mathrm{pH}$ of the external environment.

Acid-inducible changes in cell behaviour occur in Salmonella typhimurium (Aliabadi et al., 1988; Foster \& Hall, 1990, 1991; Foster et al., 1994; Lee et al., 1994), Escherichia coli (Goodson \& Rowbury, 1989a, b), Aeromonas bydrophila (Karem et al., 1994), and Rhizobium and Bradyrbizobium (O'Hara \& Glenn, 1994). Cells grown under 
Table 1. Strains and plasmids used

\begin{tabular}{|c|c|c|}
\hline Strain/plasmid & Relevant characteristics* & Source/reference \\
\hline \multicolumn{3}{|l|}{ A. tumefaciens } \\
\hline GMI9023 & C58C1, $\mathrm{Sm}^{\mathrm{r}} \mathrm{Rf}^{\mathrm{r}}$, cured of pATC58 & T. Finan $\dagger$ \\
\hline \multicolumn{3}{|l|}{ E. coli } \\
\hline DH5 $\alpha$ & $\begin{array}{l}\mathrm{F}^{-} \phi 80 \mathrm{~d} l a c Z \Delta \mathrm{M} 15 \operatorname{rec} A 1 \text { end } A 1 \text { gyr } A 96 \text { thi-1 } \\
\text { bsdR17 }\left(\mathrm{r}_{\mathrm{K}}^{-} \mathrm{m}_{\mathrm{K}}^{+}\right) \sup E 44 \text { relA1 deo } \mathrm{R} \\
\Delta(\operatorname{lac} Z Y A-\operatorname{argF}) \mathrm{U} 169\end{array}$ & BRL \\
\hline DH10B & $\begin{array}{l}\mathrm{F}^{-} m c r A \Delta(m r r-b s d \mathrm{R} M S-m c r B C) \phi 80 \mathrm{~d} l a c Z \Delta \mathrm{M} 15 \\
\Delta l a c X 74 \text { end } A 1 \text { rec } A 1 \text { deo } \Delta(\text { ara, leu }) 7697 \\
\text { araD139 galU galK nupG rpsL }\end{array}$ & BRL \\
\hline HB101 & $\begin{array}{c}\mathrm{F}^{-} \text {thi-1 bsdS20 }\left(\mathrm{r}_{\mathrm{B}}^{-} \mathrm{m}_{\mathrm{B}}^{-}\right) \sup \text { E44 rec } A 13 \text { ara-14 } \\
\text { leuB6 pro } A 2 \text { lac } Y 1 \text { rpsL20 }\left(\mathrm{Sm}^{\mathrm{r}}\right) \times y l-5 \text { mtl-1 }\end{array}$ & Boyer \& Roulland-Dussoix (1969) \\
\hline \multicolumn{3}{|c|}{ R. leguminosarum bv. trifolii } \\
\hline NA3001 & Acid $^{t}$ & J. Howieson $\ddagger$ \\
\hline TA1 & Acid $^{8}$; commercial strain for white clover & J. Howieson \\
\hline \multicolumn{3}{|c|}{ R. leguminosarum bv. viceae } \\
\hline WSM710 & Acid $^{t}$ strain from Vicia spp. in Japan & J. Howieson \\
\hline WSM937 & 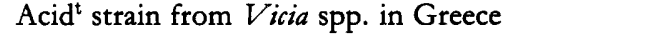 & J. Howieson \\
\hline \multicolumn{3}{|l|}{ R. meliloti } \\
\hline $\mathrm{CC} 169$ & Commercial inoculant from South Australia & \\
\hline $\operatorname{Rm} 1021$ & SU47 str-21 & T. Finan \\
\hline RT295 & actS: : : $\mathrm{Km}$ mutant of WSM419 & This study \\
\hline TG5-46 & act $\mathrm{R}:: \operatorname{Tn} 5$ mutant of WSM419 & Goss et al. (1990) \\
\hline U45 & Commercial inoculum from Uruguay & \\
\hline WSM232 & Acid $^{\mathrm{s}}$ isolate from Iraq & J. Howieson \\
\hline WSM244 & Acids isolate from Iraq & J. Howieson \\
\hline WSM419 & Acid ${ }^{\mathrm{t}}$ Sardinian isolate, $\mathrm{Cm}^{\mathrm{r}}$ & J. Howieson \\
\hline WSM540 & Acid $^{t}$ commercial strain & J. Howieson \\
\hline \multicolumn{3}{|l|}{ R. tropici } \\
\hline 5024 & Acid $^{t}$ & J. Howieson \\
\hline \multicolumn{3}{|l|}{ Plasmids } \\
\hline pGEM-7Zf(+) & Cloning vector; $\mathrm{Ap}^{\mathrm{r}}$ & Promega \\
\hline pJQ200KS & Gene replacement vector; $\mathrm{Gm}^{\mathrm{r}} \mathrm{Suc}^{\mathrm{s}}$ & Quandt \& Hynes (1993) \\
\hline pMP220 & Broad-host-range lac $Z$ fusion vector; $\mathrm{Tc}^{\mathrm{r}}$ & Spaink et al. (1987) \\
\hline pMP220-Km2 & $\begin{array}{l}\text { pMP220 derivative with } \mathrm{Km}^{\mathrm{r}} \text { interposon; } \mathrm{Km}^{\mathrm{r}} \\
\mathrm{Tc}^{\mathrm{r}}\end{array}$ & This study \\
\hline pPH1J1 & Broad-host-range IncP plasmid; $\mathrm{Gm}^{\mathrm{r}} \mathrm{Sm}^{\mathrm{r}} \mathrm{Sp}^{\mathrm{r}}$ & \\
\hline $\mathrm{pHP} 45 \Omega \mathrm{Km}$ & $\begin{array}{l}\mathrm{pHP} 45 \Omega \text { derivative with } \mathrm{Km}^{\mathrm{r}} \text { interposon; } \mathrm{Ap}^{\mathrm{r}} \\
\mathrm{Km}^{\mathrm{r}}\end{array}$ & Fellay et al. (1987) \\
\hline pRK2013 & Helper plasmid; $\mathrm{Km}^{\mathrm{r}}$ & Ditta et al. (1980) \\
\hline pRT546Cla & $\begin{array}{l}\text { pGEM-7Zf }(+) \text { containing } \mathrm{Km}^{\mathrm{r}} \text { ClaI fragment of } \\
\text { TG5-46 }\end{array}$ & Tiwari et al. (1992) \\
\hline pRT546-1 & $\begin{array}{l}\text { A } 25 \mathrm{~kb} \text { Sau3AI fragment of WSM } 419 \text { genomic } \\
\text { DNA cloned into the BamHI site of pSW } 213 \\
\text { which hybridized with the } 0.5 \mathrm{~kb} \text { SmaI-HpaI } \\
\text { probe }\end{array}$ & This study \\
\hline pRT546-6 & $\mathrm{pSW} 213$ with the $3.8 \mathrm{~kb} B g / \mathrm{II}$ act $\mathrm{S}$ fragment & This study \\
\hline pRT546-11 & $\mathrm{pSW} 213$ with the $3.7 \mathrm{~kb}$ EcoRI actR fragment & This study \\
\hline pRT546-20 & $\begin{array}{l}\text { pMP220 with the } 4 \cdot 0 \mathrm{~kb} B g l \mathrm{II}-K p n \mathrm{I} \text { act } S / a c t \mathrm{R} \\
\text { fragment }\end{array}$ & This study \\
\hline pRT546-22 & $\begin{array}{l}\text { pRT546-20 derivative, act }:: \Omega \mathrm{Km} \text {; insertion site: } \\
\text { EcoRI }\end{array}$ & This study \\
\hline pRT546-29 & $\begin{array}{l}\text { pMP220-Km2 derivative, with the potential actS } \\
\text { promoter }\end{array}$ & This study \\
\hline
\end{tabular}


$\operatorname{act} R / S$ : a two-component sensor-regulator system

Table 1 (cont.)

\begin{tabular}{|c|c|c|}
\hline Strain/plasmid & Relevant characteristics* & Source/reference \\
\hline pRT546-32 & $\begin{array}{l}\text { pMP220-Km2 derivative, with the potential act } \mathrm{R} \\
\text { promoter }\end{array}$ & This study \\
\hline pSW213 & Broad-host-range cloning vector; $\mathrm{Tc}^{\mathrm{r}}$ & Chen \& Winans (1991) \\
\hline pUC18 & Cloning vector; $A \mathrm{p}^{\mathrm{r}}$ & Yanisch-Perron et al. (1985) \\
\hline pWR546 & $\begin{array}{l}\text { The } \mathrm{Km}^{\mathrm{r}} \text { EcoRI fragment of pTG5-46 cloned into } \\
\text { EcoRI-digested pJQ200; } \mathrm{Tc}^{\mathrm{r}}, \mathrm{Km}^{\mathrm{r}}\end{array}$ & This study \\
\hline
\end{tabular}

* Abbreviations: acid-sensitive $\left(\mathrm{Acid}^{\mathrm{s}}\right)$ or tolerant $\left(\mathrm{Acid}^{\mathrm{t}}\right)$; ability to maintain alkaline intracellular $\mathrm{pH}\left(\mathrm{pH}_{i}^{+}\right)$or not $\left(\mathrm{pH}_{1}^{-}\right)$; sucrose sensitive $\left(\mathrm{Suc}^{\mathrm{g}}\right)$. Resistance to ampicillin $\left(A \mathrm{p}^{r}\right)$, chloramphenicol $\left(\mathrm{Cm}^{\mathrm{r}}\right)$, gentamicin $\left(\mathrm{Gm}^{r}\right)$, kanamycin $\left(\mathrm{Km}^{r}\right)$, rifampcin $\left(\mathrm{Rf}^{\mathrm{r}}\right)$, spectinomycin $\left(\mathrm{Sp}^{r}\right)$, streptomycin $\left(\mathrm{Sm}^{\mathrm{r}}\right)$ and tetracycline $\left(\mathrm{Tc}^{r}\right)$.

† Department of Biology, McMaster University, Hamilton, Canada.

$\ddagger$ Western Australian Department of Agriculture.

mildly acidic conditions are more resistant to a subsequent severe $\mathrm{pH}$ shock than cells grown at neutral $\mathrm{pH}$ : the socalled adaptive acid tolerance response (ATR) (Foster \& Hall, 1990; O'Hara \& Glenn, 1994) or acid habituation (Goodson \& Rowbury, 1989a, b; Raja et al., 1991a, b). Some genes involved in the cellular response to $\mathrm{pH}$ are inducible (Foster \& Hall, 1991; Foster, 1992) whereas others are constitutive (Foster \& Hall, 1991; Tiwari et al., 1996).

The isolation from Sardinia of strains of $\mathrm{R}$. meliloti like WSM419 and WSM540 with superior performance in nodulating medic species in acid soils (Howieson \& Ewing, 1986) raised the question why such strains were more acid-tolerant under field conditions than others. Tn5-induced acid-sensitive mutants have been isolated from R. meliloti WSM419 (O'Hara et al., 1989; Goss et al., 1990; Tiwari et al., 1992). These mutants grow as well as the wild-type at neutral or alkaline $\mathrm{pH}$ and effectively nodulate Medicago polymorpha. One of these acid-sensitive mutants of $R$. meliloti, strain TG5-46, fails to grow below pH 6.0 at $0.3 \mathrm{mM}$ calcium (Goss $e t$ al., 1990; Tiwari et al., 1992; Reeve et al., 1993), but will grow at pH 5.6 in the presence of $10 \mathrm{mM}$ calcium (Reeve et al., 1993). It is defective in the maintenance of $\mathrm{pH}_{i}$; as $\mathrm{pH}_{\mathrm{e}}$ drops below $7 \cdot 0, \mathrm{pH}_{\mathrm{i}}$ begins to fall (O'Hara et al., 1989).

It has been proposed (Glenn \& Dilworth, 1994) that root nodule bacteria, and other bacteria, may have some form of sensing mechanism which enables cells to respond to acidic environments. Such systems for environmental sensing and response in bacteria commonly have two components - a sensor to detect the environmental change and a regulator to control the transcriptional response (Albright et al., 1989; Stock et al., 1989; Parkinson \& Kofoid, 1992).

We now report that the acid-sensitive mutant strain $R$. meliloti TG5-46 is defective in a regulator gene and that a sensor-regulator pair is essential for acid-tolerance in the wild-type R. meliloti WSM419.

\section{METHODS}

Bacterial strains, plasmids and media. Bacterial strains and plasmids are described in Table 1. Strains of Rbizobium were grown at $28^{\circ} \mathrm{C}$ in JMM minimal medium or TY (O'Hara et al., 1989). Escherichia coli and Agrobacterium strains were grown in Luria-Bertani (LB) medium at $37^{\circ} \mathrm{C}$ and $28^{\circ} \mathrm{C}$, respectively. Media were supplemented with the following concentrations of antibiotics ( $\mu \mathrm{g} \mathrm{ml}^{-1}$ ): ampicillin (100), chloramphenicol (20), gentamicin (50), kanamycin (50) or tetracycline (20).

Tn5/interposon marker exchange. The vector PJQ200SK (Quandt \& Hynes, 1993) containing a p15A replicon was used as a suicide delivery vehicle to re-insert $\operatorname{Tn} 5$ into act $R$. The EcoRI fragment containing $\operatorname{Tn} 5$ was cut from pTG5-46, endfilled, and cloned into the SmaI site of pJQ200SK to create pWR546. This construct was then mobilized into $R$. meliloti WSM419 and transconjugants were plated on JMM pH 7.0 containing sucrose $(5 \%, w / v)$ and kanamycin. Kanamycinresistant colonies which were gentamicin-sensitive were selected for acid-sensitivity tests.

To inactivate act $S$ the $2 \cdot 3 \mathrm{~kb}$ kanamycin-resistance interposon from the plasmid pHP45 $\Omega-\mathrm{km}$ (Fellay et al., 1987) was cut out by HindIII, end-filled and then cloned into pRT546-20 at the endfilled EcoRI site. This new clone pRT546-22, having the interposon inserted at the 295th codon of actS, was mobilized into $R$. meliloti WSM419 by triparental mating using the helper plasmid pRK2013. The transconjugants of WSM419 having pRT546-22 were selected on TY plates containing chloramphenicol, kanamycin and tetracycline. The incompatible plasmid pPH1J1 was mobilized into WSM419(pRT546-22) and transconjugants were selected on TY plates containing chloramphenicol, kanamycin and gentamicin. Kanamycin-resistant colonies which were tetracycline-sensitive were selected for acid-sensitivity tests.

Acid sensitivity was established by patching transconjugants onto JMM (pH 5.7). The acid-sensitive phenotype was subsequently confirmed by spotting $10^{4}$ cells onto JMM minimal medium ( $\mathrm{pH} 7.0$ or 5.7 ) containing various concentrations of calcium (Reeve et al., 1993).

DNA preparation and manipulation. Plasmid DNA was extracted by the alkaline lysis technique and purified by $\mathrm{CsCl}$ /ethidium bromide isopycnic centrifugation (Sambrook et 
al., 1989). Genomic DNA was isolated using a procedure essentially similar to that of Goss et al. (1990) except that after phenol/chloroform extraction, the aqueous phase was dialysed against TE buffer at room temperature overnight followed by five changes at $4^{\circ} \mathrm{C}$ over $3 \mathrm{~d}$.

Construction of a DNA probe. A $0.5 \mathrm{~kb}$ SmaI-HpaI fragment (Fig. 1a) was used as a probe in hybridization studies. The $0.5 \mathrm{~kb}$ fragment was purified by electrophoresis on a $1 \%(\mathrm{w} / \mathrm{v})$ agarose gel and transferred into a $0.4 \%$ SeaPlaque GTG agarose gel (FMC Corporation). DNA was recovered using Agarase (Boehringer Mannheim) and ethanol precipitation, resuspended and then labelled with digoxigenin-11-dUTP (Boehringer Mannheim) as described by the manufacturer.

Southern hybridization. EcoRI-digested genomic DNA from different rhizobial strains was separated on $0.7 \%$ agarose, denatured, blotted and UV crosslinked onto nylon membranes (Boehringer Mannheim). Prehybridization and hybridization were performed at $42^{\circ} \mathrm{C}$; high-stringency washing conditions were as described by Tiwari et al. (1992). The chemiluminescent substrate AMPPD (Boehringer Mannheim) was used to detect the hybridized digoxigenin-labelled probe.

DNA sequencing and analysis. DNA sequencing was carried out using an Applied Biosystems Prism Ready Reaction kit and automated DNA sequencer. The pUC/M13 Forward ( -47 ; 24-mer) and Reverse (22-mer) primers were purchased from Promega Corporation. Custom-made oligonucleotides were chemically synthesized and purified by Bresatec. The $\operatorname{Tn} 5$ primer was a 25 -mer oligonucleotide containing the sequence 5'-TAC GAG GTC ACA TGG AAG TCA GAT C-3'. One custom primer was used which contained the sequence $5^{\prime}-C G T$ AGA CGC GCT GGA TAT GC-3' (positions 2110-2091 in Fig. 2). DNA sequences were analysed using the MacVector 3.5 sequence analysis programs from IBI. The FASTA (Pearson \& Lipman, 1988) and CLUSTAL w (Thompson et al., 1994) analysis programs were accessed via The Australian National Genomic Information Service (ANGIS) located at the University of Sydney.

lacz-fusion studies. The wide-host-range vector pMP220 (Spaink et al., 1987), containing a promoterless lac $Z$, was modified and used for fusion studies. $\beta$-Galactosidase was assayed as described by Miller (1972) and protein concentration was measured using a Bio-Rad protein assay kit. $\beta$-Galactosidase specific activity was expressed as nmol 0 -nitrophenol produced $\mathrm{min}^{-1}$ (mg protein) $)^{-1}$ at $28^{\circ} \mathrm{C}$.

\section{RESULTS AND DISCUSSION}

\section{TG5-46 is an acid-sensitive mutant}

The acid-sensitive mutant TG5-46 was isolated by $\mathrm{Tn} 5$ mutagenesis of $R$. meliloti WSM419. Unlike its parent strain, which could grow down to $\mathrm{pH} 5 \cdot 6$, TG5-46 was unable to grow below pH 6.0 in JMM (O'Hara et al., 1989). Southern hybridization revealed that a single copy of $\mathrm{Tn} 5$ was present in the genome of TG5-46 (Goss et al., 1990). The EcoRI fragment containing Tn 5 from TG5-46 was cloned into pUC18 and pJQ200SK to construct pTG5-46 and pWR546, respectively. Tn5 marker exchange, in which pWR546 was mobilized into R. meliloti WSM419, generated kanamycin- and sucrose-resistant transconjugants. These were also acid-sensitive, showing that the acid-sensitive phenotype in TG5-46 is directly linked to the presence of $\operatorname{Tn} 5$. (a)

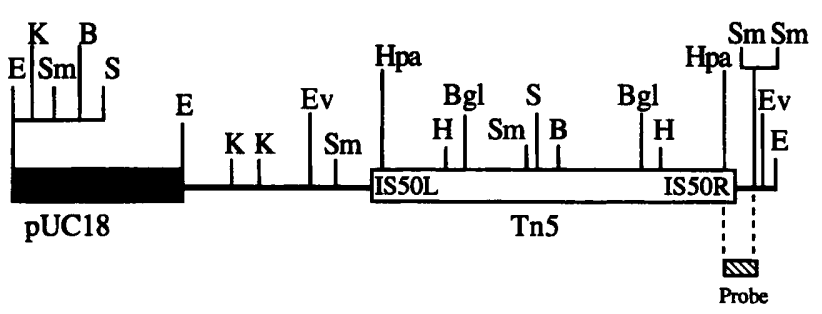

(b)

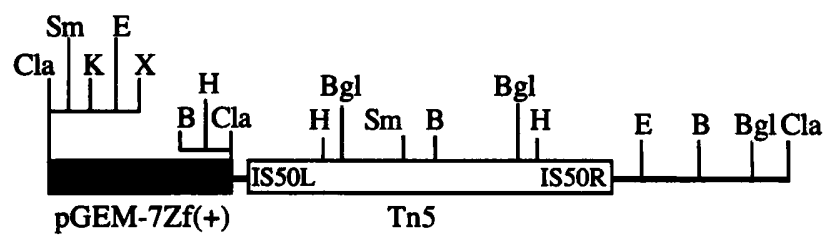

\begin{tabular}{llllll}
0 & 1 & 2 & 3 & 4 & 5 \\
\hline
\end{tabular}

Fig. 1. Restriction mapping of the actR gene region in $R$. meliloti WSM419. (a) Amended restriction map of pTG5-46 as determined in this study. The region of DNA used as a probe in hybridization studies is presented as a hatched box. (b) Restriction map of pRT5-46Cla. This construct contains the $\mathrm{Km}^{r}$ Clal fragment from TG5-46 cloned into the Clal site of pGEM7Zf(t). Restriction sites are as follows: B, BamHI; Bgl, Bg/ll; Cla, Clal; E, EcoRI; Ev, EcoRV; H, HindIII; Hpa, Hpal; K, Kpnl; S, Sall; Sm, Smal; X, Xhol.

\section{Restriction mapping of DNA}

The rhizobial DNA fragment flanking the IS50R of pTG5-46 ended at the EcoRI site only $0.6 \mathrm{~kb}$ from Tn5 and therefore another genomic DNA fragment from TG5-46 was cloned in order to obtain more sequence information. A ClaI fragment from TG5-46 genomic DNA, carrying the kanamycin resistance determinant, was cloned into the ClaI site of pGEM-7Zf( +$)$ to construct pRT546Cla, which provided approximately $2.5 \mathrm{~kb}$ of DNA after the EcoRI site on the right-hand flanking sequence (Fig. 1).

\section{Sequencing and analysis}

Rhizobial DNA subcloned from pTG5-46 and pRT546Cla into either pGEM7Zf(+) or pUC18 was sequenced. The DNA around the $\mathrm{Tn} 5$ insertion has been fully sequenced on both strands (Fig. 2) from the $B a m \mathrm{HI}_{2}$ site of the rhizobial DNA flanking the IS50R (Fig. 1b) to the $E_{c o R V_{263}}$ site flanking the IS5OL (Fig. 1a).

During the subcloning of DNA from pTG5-46, it was established that the $K p n \mathrm{I}$ and $H p a \mathrm{I}$ sites originally reported in the rhizobial DNA flanking the IS50R of Tn5 by Goss et al. (1990) were incorrect; the restriction map of pTG5-46 has therefore been amended. The sequencing data confirmed the amended restriction map and also 
-GG ATC CCG CCA ACG CCA TGC CGA CAA CGC GCG CCA AGC CAC GCG GCG CTT AAC CCC ATt TGA TAA TTG CCG GGT TCG GCA TAA AGT TCG 90 GTA GGA CGA ACT GAT GCG GCC GCA TGC GGC CGC ATC GCG GAA TGG AAA CGC ATG GCA GCC TCA ACG CTC TAC AAT GAC CTG AAC AGC AAT 180 ORF1 (actS)

CGC AGC CTC AGA CTT CAG ACG CTC GTG CGG CTG CGC TGG CTG GCG GTG GGC GGA CAA TTG CTA GCC GTT ATC GTC ACG GCG CTT TGG CTG

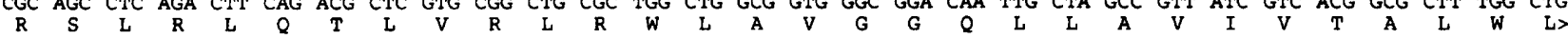
CAG TTC CCC CTG CCG ATC GTC CCC TGT TCG GTT CTG ATT GCC TGC CTG GCA CTC GTC AAC GTC ATT CTC ACA TTG CGG TTT CCG CCT ACG CAG CGG CTG ACG CCG CCG GCC GCT TTC GCC CTG CTC GGC CTG GAT CTG GCG CAA CTC ACC GCC TTG CTC TTC ATC ACC GGC GGG CTT GCC

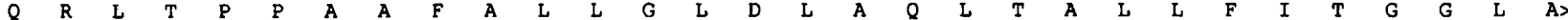
AAC CCC TTT GCG CCG CTT CTC TGC GTT CCG GTC ATC ATC TCT TCG GCC TCG CAG CCG AAG CCT CAC AGC ATC GTG CTG GCC GTG TTT GCC GTC GTG GGC GTC ACC GCG CTC GCC TTC TCG CCC TTC CAG CTG CCC TGG TAT CCG GGG ACC GTT CTG CTG ATC CCG CAC GTG CTG ACG GCC $\mathrm{V} V \mathrm{~V}$ G $\mathrm{V}$ T

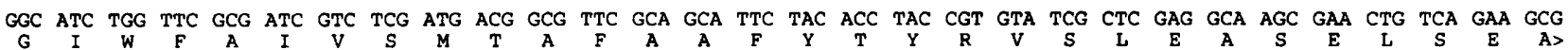
CTG ACC GCC ACC GAA CTC GTG CTC CAG CGC GAA AAG CAC CTG TCG CAA CTC GAC GGG CTC GCA GCC GCC GCC GCG CAC GAA CTC GGA ACG CCG CTT GCG ACG ATC AGC GTC GTA GCC AAG GAG ATG GAA CGG GAG CTC GGC GAC GAT CCT CGT TTC GGC GAA GAC GTC CAC CTC CTG CGC AGC CAG AGC GAG CGC TGC CGA GAC ATA CTG AGG CGG CTC ACG ACG CTT TCT TCG GAG AGC GAG GAA CAT ATG CGA CTT CTG CCG CTC TCG

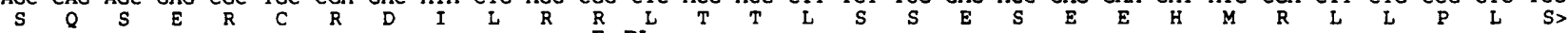
TCC CTT ATC GAG GAG GTG ATG GCG CCG CAT CGC GAA TTC GGA ATC GAA ATC GAG CTG AAG GAG CAG GGC GAA CGC GCC ACG GAG CCC GTC 1080

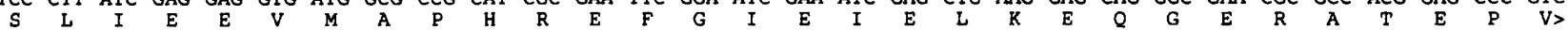
GGC ATC CGC AAT GCA GGC ATT CTC TAT GGC CTG GGA AAC CTG CTG GAA AAC GCG GTC GAC TAT GCG CGC AAG AAA GTG ACG GTC ACG ACG 1170

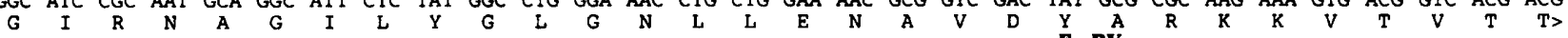

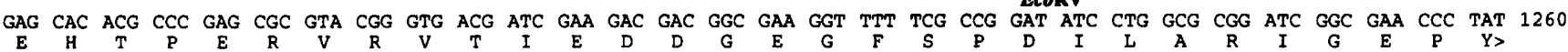
GTG ACG CGG CGT CAG AAG GAC GAC AGT GCC GGC GGG CTC GGG CTC GGG CTC TTC ATC GCC AAG ACG CTG CTC GAG CGT TCG GGT GCC CGG 1350

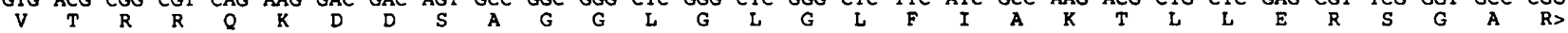
CTG CGC TTC GAG AAC GGT GGA GCC AAA CAC CCG GGT GCC CGG GTC AGC GTC GAA TGG CCG CGC GCG CTG ATG GAC TCG AAA CTG GCG AAA 1440

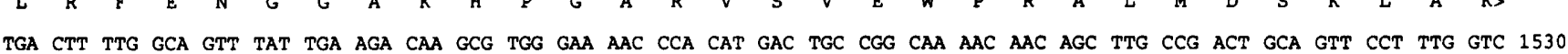
CCA CCG TTC AAA GGA CAT GCG GAA ACT GTT ACA GGT TAC AGA AGC CAT TGC GCG TCC GGC TGG ACG CGC GGC GCT GTA GGG GTT TGA GAA 1620 ATG ATC GAA AAG TCG ACG CCT GCG CCA ATC ACC CAC GCC GCG GAT GCG GAC CTG ATC GGA CCC GAC AAG AGC CTT CTG ATC GTC GAT GAC 1710

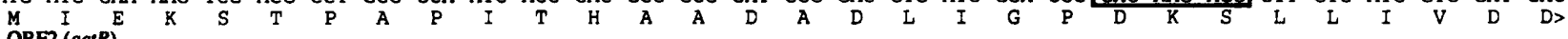
GAC ACC GCT TTT CTG CGG CGC CTC GCC CGC GCG ATG GAA GCG CGC GGC TTC GCG GTA GAG ATC GCC GAG TCG GTT GCC GAA GGC ATA GCC 1800

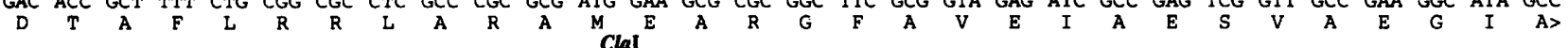

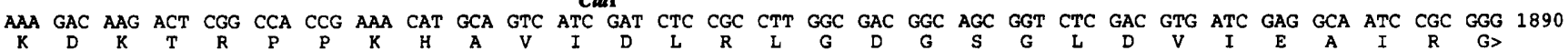

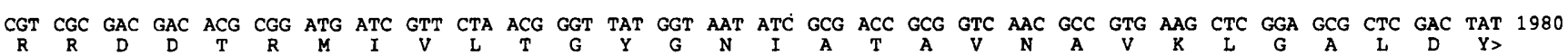
CTG GCA AAA CCG GCG GAC GCC GAT GAC ATT CTC GCA GCA TTG ATT CAG CGC CCG GGC GAA CGG GTA GAG CCC CCG GAG AAC CCC ATG TCG 2070

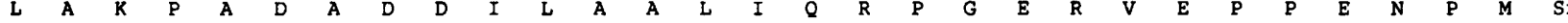
GCG GAC CGC GTC CGA TGG GAG CAT ATC CAG CGC GTC TAC GAA ATG TGC GAA CGC AAT GTT TCG GAA ACG GCG CGC CGG CTA AAC ATG CAC 2160 CGG CGG ACC TTG CAG CGC ATT CTG GCG AAA CGG GCC CCG AAA TAG GCC GGC GGC GGA TGA GGG GCA AAT CTC GGG AGC GCT CTA GTC CCG 2250

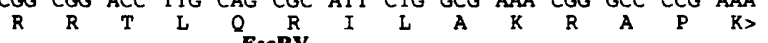
CCC CCC GCT TAC GAT ATC

Fig. 2. Nucleotide sequence of the cloned rhizobial DNA flanking the site of Tn5 insertion in $R$. meliloti TG5-46. The boxed region represents the 9 bp which were duplicated by Tn 5 insertion in TG5-46. Potential ribosome-binding sites are underlined. The predicted amino acid sequence of the ActS and ActR proteins is presented in single-letter code below the nucleotide sequence. Restriction sites of the DNA sequence are shown in bold.

established the presence of an additional SmaI site on the rhizobial DNA flanking the IS50R separated by only two bases from the previously identified site (Fig. 1a).

Analysis of the DNA sequence using the MacVector program revealed the presence of two open reading frames: ORF2 spanned the site of Tn 5 insertion; ORF1 started at nucleotide position 142 and ended at 1440 in the DNA sequence presented in Fig. 2. A putative ribosomebinding site (5'-GGAAA-3') was located 3 bp upstream from the ATG initiation codon of ORF1. ORF2, which started at position 1621, continued through the site of Tn 5 insertion at 1683 and ended at 2202, had a potential ribosome-binding site ( $\left.5^{\prime}-\mathrm{GAGAAA}-3^{\prime}\right)$ starting $5 \mathrm{bp}$ upstream from the start codon (Fig. 2).

\section{$\operatorname{actR}$}

The computer-predicted protein from ORF2 contains 193 amino acids and has an estimated molecular mass of $21463 \mathrm{Da}$ and a pI of 8.3. A search of databases using the 


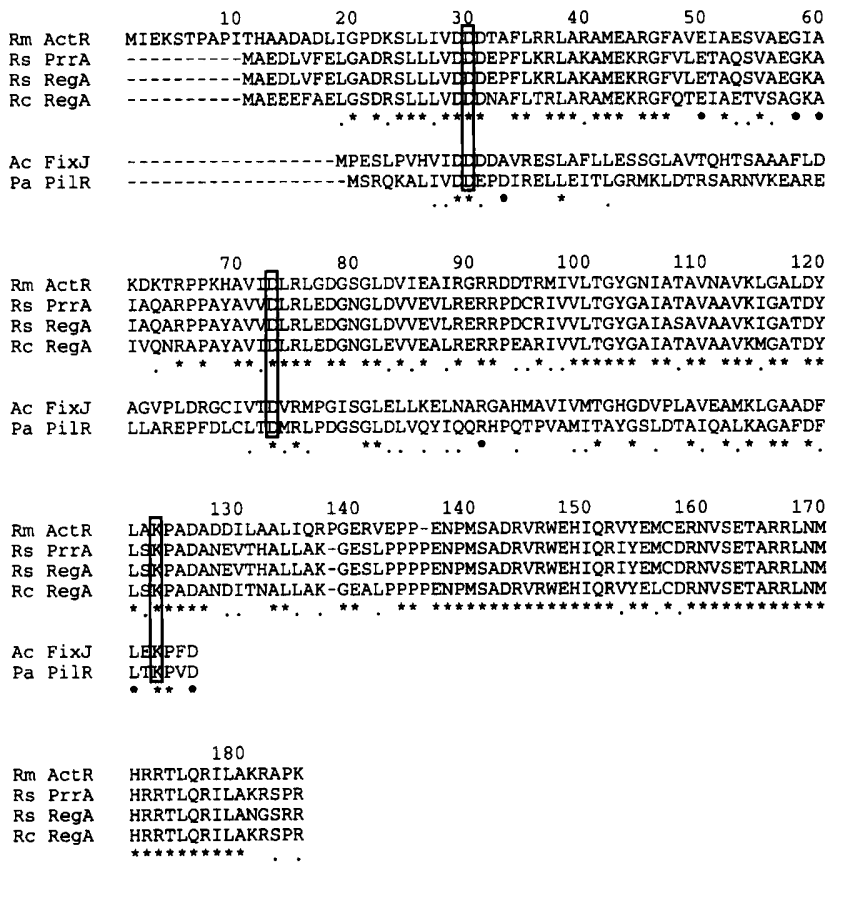

Fig. 3. CLUSTAL W alignment of $R$. meliloti WSM419 ActR with the amino acid sequences of five other response regulators. The numbers on the top line indicate the amino acid residue numbering of ActR. Residues conserved among all the response regulators are highlighted with an asterisk. Similar residues are marked with a dot. The highly conserved amino acids in the response regulators are boxed. An explanation of abbreviations used for bacterial strains is provided in the legend of Table 2.

FASTA program indicated that the protein encoded by ORF2 showed significant similarity with proteins such as $\operatorname{Prr} A, \operatorname{Reg} A$, NtrC, Fix J and PilR, which are the regulator components of sensor-regulator protein pairs involved in signal transduction in prokaryotes (Stock et al., 1989; Parkinson \& Kofoid, 1992). ORF2, tentatively identified as coding for a regulatory protein, has been designated as act $\mathrm{R}$.

The proteins showing similarity with the ActR sequence are involved in responding to a diverse range of environmental stimuli. These proteins show similarity in their N-terminal portions. The program CLUSTAL w was used to align five selected sequences with ActR (Fig. 3). The invariant aspartate and lysine residues conserved between regulatory proteins are also found in ActR and have been boxed. The Asp-30, Asp-73 and Lys-123 residues of ActR appear to correspond to residues Asp-13, Asp-57 and Lys-109 in CheY. These N-terminal amino acid residues of the regulators are clustered at the end of what is thought to be a $\beta$-sheet, as found in CheY (Stock et al., 1989). This region of the response-regulator is thought to correspond to an active site in these proteins, consistent with the finding that Asp-57 is phosphorylated in CheY (Stock et al., 1989).

Although the majority of these regulator sequences align only to the N-terminal portions of ActR, RegA from $R$ hodobacter capsulatus and Rhodobacter sphaeroides and $\operatorname{Prr} A$ from $R$. sphaeroides showed a high degree of similarity to ActR over the entire amino acid sequence. The ActR protein showed $71.2 \%$ and $69 \cdot 8 \%$ identity to the RegA protein from R. capsulatus and R. sphaeroides, respectively, and $87.0 \%$ similarity to $\operatorname{RegA}$ from either species. $\operatorname{Prr} A$, which is closely related to RegA, showed $70 \cdot 1 \%$ identity and $87.0 \%$ similarity with ActR (Table 2).

The specificity of the CLUSTAL $w$ analysis was increased by aligning the PrrA and RegA proteins to ActR as shown in Fig. 3. In this case, identical residues were found to align throughout the amino acid sequence of ActR, with the greatest similarity occurring in the C-terminus. The high

Table 2. Similarity of ActS/ActR to other sensor-regulator pairs involved in signal transduction

\begin{tabular}{|c|c|c|c|c|c|}
\hline \multirow{2}{*}{$\begin{array}{l}\text { Sensor-regulator } \\
\text { pair* }\end{array}$} & \multicolumn{3}{|c|}{ Protein match } & \multirow[t]{2}{*}{ System $t$} & \multirow[t]{2}{*}{ Reference } \\
\hline & $\begin{array}{l}\text { Over no. of } \\
\text { amino acids }\end{array}$ & $\begin{array}{c}\% \\
\text { identity }\end{array}$ & $\begin{array}{c}\% \\
\text { similarity }\end{array}$ & & \\
\hline Rs PrrB & 428 & $42 \cdot 1$ & $71 \cdot 0$ & Photosynthesis & Eraso \& Kaplan (1995) \\
\hline Rs PrrA & 177 & $70 \cdot 1$ & $87 \cdot 0$ & (Oxygen) & Eraso \& Kaplan (1994) \\
\hline Rs RegB & 427 & $41 \cdot 7$ & $71 \cdot 0$ & Photosynthesis & Qian \& Tabita (1996) \\
\hline Rs RegA & 172 & $69 \cdot 8$ & $87 \cdot 3$ & (Oxygen) & Phillips-Jones \& Hunter (1994) \\
\hline Rc RegB & 410 & $38 \cdot 5$ & $65 \cdot 6$ & Photosynthesis & Mosley et al. (1994) \\
\hline Rc RegA & 177 & $71 \cdot 2$ & $87 \cdot 0$ & (Oxygen) & Sganga \& Bauer (1992) \\
\hline Ac FixL & 273 & $31 \cdot 9$ & $58 \cdot 9$ & Nitrogen fixation & Kaminski \& Elmerich (1991) \\
\hline Ac Fix J & 119 & $36 \cdot 1$ & $61 \cdot 3$ & (Oxygen) & Kaminski \& Elmerich (1991) \\
\hline Pa Pils & 234 & $26 \cdot 5$ & $55 \cdot 1$ & Pilin synthesis & Boyd et al. (1994) \\
\hline Pa PilR & 122 & $36 \cdot 1$ & $66 \cdot 4$ & (?) & Ishimoto \& Lory (1992) \\
\hline
\end{tabular}

* Proteins are from the following sources: Ac, Azorbizobium caulinodans; $\mathrm{Pa}$, Pseudomonas aeruginosa; Rc, Rhodobacter capsulatus; Rs, Rhodobacter sphaeroides.

†Proposed signals for these systems are given in parentheses. The question mark designates an undetermined signal. 
act $\mathrm{R} / \mathrm{S}:$ a two-component sensor-regulator system

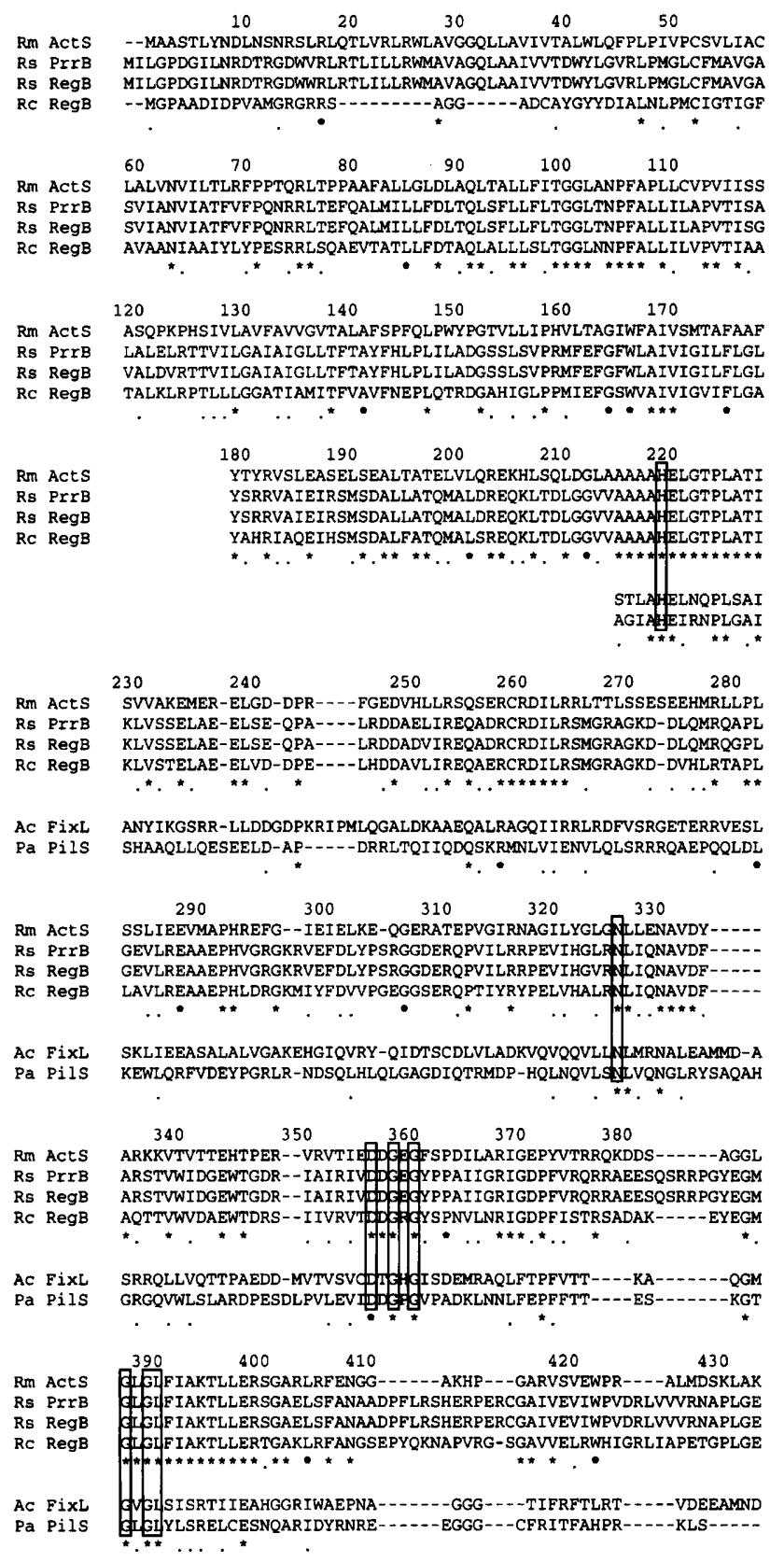

Fig. 4. CLUSTAL W alignment of $R$. meliloti WSM419 ACtS with the amino acid sequence of five other histidine protein kinases. Conserved residues are highlighted with an asterisk and similar residues are marked with a dot. The numbers on the top line indicate the amino acid residue numbering of ActS. The highly conserved amino acids in the sensors of two-component sensor-regulator systems (histidine, asparagine, aspartic acid and glycine) are boxed. An explanation of abbreviations used for bacterial strains is provided in the legend of Table 2. Only the kinase domains of $\mathrm{AC}$ FixL and $\mathrm{Pa}$ PilS are shown. Introduction of a frameshift change to the sequence of regB from $R$. capsulatus for the first 40 codons would generate a reading frame yielding a protein with a higher degree of similarity between Rc RegB and Rs PrrB.

degree of similarity between the normally variable Cterminal domains suggests that these proteins might have a similar mode of action.
The environmental response-regulators have been subgrouped into several classes on the basis of the similarity of their $\mathrm{C}$ termini. The main classes include the $\mathrm{NtrC}$ subclass, the OmpR subclass and the Fix J subclass (Stock et al., 1989; Bourret et al., 1991). Using a different selection criterion, Parkinson \& Kofoid (1992) have designated these as the ROII, ROIII and ROIV classes. Eraso \& Kaplan (1994) have suggested that PrrA and RegA be placed into a new subgroup since their $C$ termini are different from those of other regulators. We propose that ActR should be included in this subgroup. Although these proteins lack a known DNA-binding motif it is still possible that they bind to DNA sequences. Such is the case for OmpR (a member of the ROII family), which does not have a helix-turn-helix motif (Nara et al., 1986) but binds to promoter sequences upstream of ompC and $o m p F$ (Tate et al., 1988). Alternatively, RegA, PrrA or ActR could act as intermediaries (as seen with CheY, SpoOF and $\mathrm{CheB}$ ) by interacting with other proteins in more complex regulatory cascades (Bourret et al., 1991).

\section{acts}

Response-regulatory proteins interact, directly or indirectly, with a sensor protein, forming two-component sensor-regulator protein pairs. The sensor component detects an environmental stimulus through its $\mathrm{N}$-terminal domain and activates the $\mathrm{C}$-terminal kinase activity of the sensor protein (Stock et al., 1989). Activated sensor protein phosphorylates the $\mathrm{N}$-terminal domain of the regulatory protein, which then executes the response. Different sensors show homology at the C-terminal region since this is the domain that contains kinase activity. The gene encoding the sensor protein component is often located near the regulator gene (Wanner, 1992). It was therefore plausible that a sensor gene could be located next to actR.

The other ORF (ORF1 in Fig. 2) was located on the same strand and potentially transcribed in the same direction as $a c t R$. Conversion of this ORF into the corresponding amino acid sequence revealed that this protein would contain 433 amino acids, and have an estimated molecular mass of $47208 \mathrm{Da}$ and a $\mathrm{pI}$ of $6 \cdot 2$. From a search of protein databanks using the FASTA program the top ten scores obtained were to sensor histidine kinase proteins of two-component sensor-regulatory systems. The FASTA analysis revealed that the greatest similarity occurred in the C-terminal region of these proteins. ORF1, tentatively identified as coding for a sensor protein, has therefore been designated as act $S$.

CLUSTAL w analysis was used to align ActS with five other sensors (Fig. 4). ActS contains the three C-terminal regions possessing the invariant residues (boxed in Fig. 4) found in all proteins of the histidine kinase family. The first of these contains a histidine (normally the site of autophosphorylation) with a space of around 100 amino acids to an asparagine found in the second region. In ActS, these amino acid residues correspond to His-219 and Asn-326, separated by 107 amino acids. The third conserved region contains two glycine-rich regions 


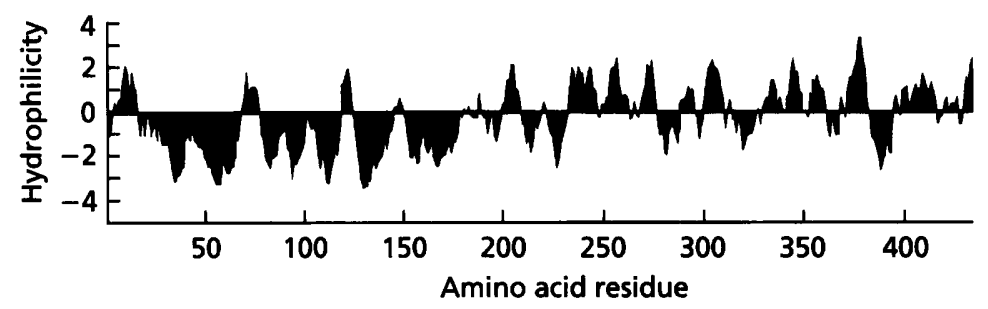

Fig. 5. Hydrophilicity analysis of the predicted amino acid sequence of the ActS protein using the MacVector analysis program and a window size of 7. Positive values indicate hydrophilic regions; negative values indicate hydrophobic regions.

separated by $20-50$ amino acids. In ActS, these include Asp-Asp-Gly-Glu-Gly-356 (Asp-X-Gly-X-Gly region), separated by 26 amino acids from Gly-Leu-Gly-387 (Gly$\mathrm{X}-\mathrm{Gly}$ region). Parallel to the high homology of ActR with $\operatorname{Reg} \mathrm{A}$ and $\operatorname{PrrA}$, ActS also showed very high similarity with RegB from R. capsulatus (38.5\% identity and 65.6\% similarity) and R. sphaeroides ( $41.7 \%$ identity and $71.0 \%$ similarity) and $\operatorname{Prr} B$ from $R$. sphaeroides (42.1\% identity and $71.0 \%$ similarity), the sensor partners of $\operatorname{Reg} A$ and $\operatorname{Prr} A$, respectively (Table 2, Fig. 4). Although the $\operatorname{prr} A / B$ and $\operatorname{reg} A / B$ pairs showed very high similarity with the act $\mathrm{R} / S$ pair, they differed in gene organization. act $R / S$ are contiguous genes transcribed in the same direction (Fig. 2), while $\operatorname{reg} A / B$ (Mosely et al., 1994) and $\operatorname{prr} A / B$ (Eraso $\&$ Kaplan, 1995) are each separated by one gene and transcribed divergently.

PrrB, RegB and FixL belong to sensory systems that respond to oxygen (Mosley et al., 1994; Eraso \& Kaplan, 1995; Monson et al., 1995; Qian \& Tabita, 1996) and it is possible that ActS also responds to the level of oxygen in the environment. However, the role of oxygen in acid tolerance in Rhizobium is unknown and currently under investigation. Both $\operatorname{Reg} A$ and $\operatorname{Prr} A$ are responsible for trans-activating expression of the photosynthetic apparatus under oxygen-deprivation conditions. RegA functions to induce the puc, puf or pub operons under anaerobic conditions (Sganga \& Bauer, 1992). A reg $A$ mutant forms photosynthetic spectral complexes, but is unable to photosynthesize under conditions of low light. PrrA is thought to be a global regulator of photosynthetic gene expression which functions to induce the cytoplasmic membrane invagination required to encapsulate the photosynthetic spectral complexes under anaerobic conditions (Eraso \& Kaplan, 1994). Under appropriate conditions, $\operatorname{Prr} A$ positively regulates the transcription of $c y c A$, $p u c$, puf and $p u b A$. Unlike $\operatorname{reg} A$ mutants, a mutation in $\operatorname{prr} A$ completely abolishes the ability to photosynthesize. The high degree of similarity between RegA/B, PrrA/B and ActR/S implies a similar mechanism of regulating gene expression.

The majority of sensors are membrane-associated molecules containing at least two membrane-spanning regions with a periplasmic loop which makes up a postulated receptor domain (Stock et al., 1989). Determination of the hydrophilicity of the peptide sequence using the Kyte \& Doolittle algorithm revealed that the $\mathrm{N}$-terminal half of ActS contained five strongly hydrophobic domains (Fig. 5 ), implying that this portion of the protein is embedded in the cytoplasmic membrane. There are at least three major hydrophilic domains (Fig. 5) which could protrude from the membrane and play a role in sensory input.

\section{Inactivation of sensor}

The DNA sequence data suggest that a two-component sensor-regulator system is involved in the response of $R$. meliloti to acidity. Inactivation of act $\mathrm{R}$ results in acid sensitivity and therefore the phenotype of an act $S$ mutant was of interest. Out of fifty kanamycin-resistant colonies obtained by interposon marker exchange, six showed tetracycline sensitivity, indicating the loss of pMP220. All six clones were acid-sensitive, failing to grow below $\mathrm{pH} 6.0$, thus demonstrating that inactivation of act $S$ leads to a loss of acid tolerance. One of these mutants, RT295, was used in further studies.

\section{Complementation}

A DNA library of the acid-tolerant strain $R$. meliloti WSM419 (Tiwari et al., 1996) was screened using a digoxigenin-labelled $0.5 \mathrm{~kb} S m a \mathrm{I}-\mathrm{H} p a \mathrm{I}$ fragment as a probe. One clone, pR T546-1, containing a $25 \mathrm{~kb}$ rhizobial DNA insert, hybridized with the probe and complemented the acid-sensitive defect of TG5-46. pRT546-1 was subcloned to create clones pRT546-20, containing both act $\mathrm{R}$ and act $S$, and $\mathrm{pRT}$ T46-11, containing act $\mathrm{R}$ only. Clone pRT546-6, which contained only act $S$, was subcloned from pRT546Cla. Clone pRT546-20, carrying both act $S$ and act $R$, complemented the acid-sensitive defect in both TG5-46 (actR) and RT295 (actS); pRT5466 , containing only actS, complemented RT295, but not TG5-46; and pRT546-11, which carried only actR, complemented both mutants (Fig. 6). These results indicate that act $\mathrm{R}$ in multiple copies can complement the defect in actS in strain RT295. In other sensor-regulator systems, it has been suggested that multiple copies of the regulator can either bypass the need for phosphorylation or allow cross-talk phosphorylation by other sensors (Stock et al., 1989).

\section{Distribution of actR/actS}

Since strains of $R$. meliloti differ in their sensitivity to soil acidity, it is important to know whether act $\mathrm{R} /$ act $S$-like genes are found only in the acid-tolerant strains, or whether they also occur in acid-sensitive strains. Genomic DNA from a range of acid-tolerant and acid-sensitive strains was therefore digested with EcoRI and the fragments were separated electrophoretically and probed 
(a)

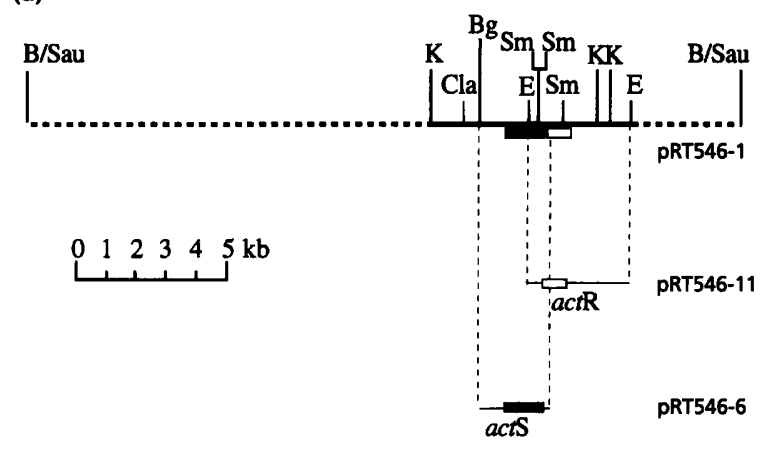

(b)

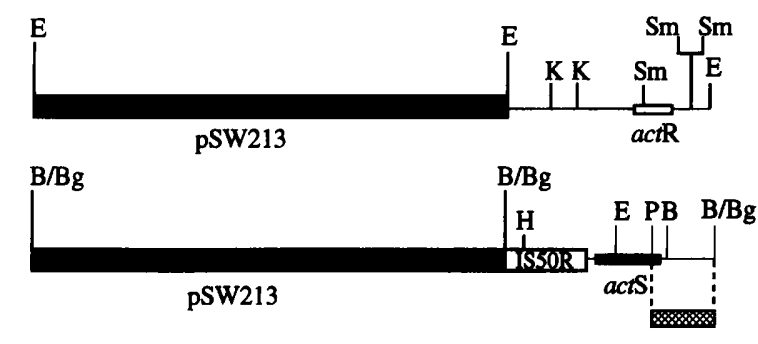

Complementation of the acid-sensitive defect in: TG5-46 RT295 (actR::Tn5) (acts:: :Km)

$+$

$+$

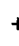

$+$

RT546-11

pRT546-6
Fig. 6. (a) Restriction map of the $25 \mathrm{~kb} R$. meliloti WSM419 DNA insert in pSW213 clone PRT546-1. The filled box represents acts; the open box represents act $R$. Complementation of the acid-sensitive defect of TG5-46 or RT295 by PRT546-1, pRT546-11 or PRT546-6 is indicated. The bold dashed lines represent incompletely restriction mapped regions. (b) Restriction maps of the subclones PRT546-11 and PRT546-6. The cross-hatched box represents the DNA used for constructing the clone pRT546-29. Restriction sites are as follows: $B$, BamHI; Bgl, Bglll; Cla, Clal; E, EcoRl; $\mathrm{H}_{\text {, }}$ Hindlll; K, Kpnl; P, Pstl; Sau, Sau3Al; Sm, Smal. with the $0.5 \mathrm{~kb} S m a \mathrm{I}-H p a I$ fragment (data not shown). The acid-tolerant strains of R. meliloti (WSM419 and WSM540) and the acid-sensitive strains (WSM232, WSM244, CC169, Rm1021 and U45) all had a single EcoRI fragment that hybridized with the probe. This indicates that this sensor-regulator system is present in all seven $R$. meliloti strains tested irrespective of their acid sensitivity or tolerance. It will be interesting to see if the acid-sensitive and acid-tolerant strains of $R$. meliloti differ because of act $R / S$ or the genes regulated by this pair. At high stringency there was no hybridization of the probe to genomic DNA from $R$. leguminosarum bv. viciae WSM710 or WSM937, R. leguminosarum bv. trifolii NA3001 or TA1, R. tropici 5024, Agrobacterium tumefaciens GMI9023 or E. coli DH5 $\alpha$ (data not shown).

\section{Expression of actR and actS}

The inactivation of act $R$ or actS in R. meliloti WSM419 results in an acid-sensitive phenotype. Complementation analysis has shown that pRT546-20 repaired the actS defect in RT295, whereas pRT546-11 complemented the act $\mathrm{R}$ defect in TG5-46. This suggests that there are promoters upstream of each of these genes. Expression from these potential promoters was analysed in pMP220$\mathrm{Km} 2$. This latter vehicle was constructed by inserting a $2.3 \mathrm{~kb}$ blunted HindIII kanamycin-resistant omega interposon from $\mathrm{pPH} 45 \Omega-\mathrm{Km}$ (Fellay et al., 1987) into a blunted $\mathrm{Bg} / \mathrm{II}$ site of the broad-host-range lac $Z$ expression vector pMP220 (Spaink et al., 1987). The kanamycinresistance gene flanked by $\mathrm{T} 4$ translation/transcription termination signals was orientated in such a way that its own transcription was in the opposite direction to that of lac $Z$. This modified vector had three advantages over using pMP220: (a) termination signals before the start codon of the lac $Z$ gene should prevent any readthrough transcription originating upstream, (b) kanamycin resistance can be used as a selection pressure for the construct since tetracycline appears to be antagonistic to cells at low pH (Goss et al., 1990), and (c) the $2.3 \mathrm{~kb}$ omega interposon insert aids in the visualization of any small insert cloned into this vector when the DNA is cut by the appropriate enzyme.

The clone pRT546-29 had a $1 \cdot 2 \mathrm{~kb}$ BglII-PstI fragment (Fig. 6) and pRT546-32 had a $0 \cdot 24 \mathrm{~kb}$ SmaI $_{1389}-S_{\text {Sal }} \mathrm{I}_{1631}$ fragment (Fig. 2) in pMP220-Km2, which should contain the act $S$ and act $R$ promoters, respectively. These clones were mobilized into $R$. meliloti WSM419 and $\beta$ galactosidase activity was measured in cells cultured at neutral and acidic $\mathrm{pH}$ (Table 3 ). The results showed that the $\beta$-galactosidase expression originating from the rhizobial DNA inserts was constitutive irrespective of the $\mathrm{pH}$ at which the cells were grown.

The marked similarity between ActR and RegA and PrrA, coupled with the equally marked similarity between ActS and $\operatorname{RegB}$, raises the question of why sensor-regulator systems from such apparently diverse organisms as $R$. meliloti and the photosynthetic bacteria $R$. sphaeroides and $R$. capsulatus should be similar. The suggestion that root nodule bacteria originated via a common photosynthetic ancestor (Sprent, 1990) and the finding that $R$. meliloti falls 
Table 3. Specific activity of $\beta$-galactosidase from cells grown in JMM minimal medium at different $\mathrm{pH}$

\begin{tabular}{|c|c|c|c|}
\hline \multirow[t]{2}{*}{ Clone } & \multicolumn{3}{|c|}{$\begin{array}{c}\text { Specific activity } \\
{\left[\text { nmol } \text { min }^{-1}(\text { mg protein })^{-1}\right]}\end{array}$} \\
\hline & pH 7.0 & pH 6.0 & pH 5.8 \\
\hline $\begin{array}{l}\text { WSM419/PRT546-29 } \\
\text { (PactS) }\end{array}$ & 1071 & 759 & 1258 \\
\hline $\begin{array}{l}\text { WSM419/pRT546-32 } \\
\text { (PactR) }\end{array}$ & 5856 & 5950 & 7153 \\
\hline
\end{tabular}

within the alpha subdivision of the Proteobacteria on the basis of 16S rRNA phylogeny (Young et al., 1991) offer a possible explanation in direct relatedness.

However, the ActS/ActR system in R. meliloti appears to be concerned with response to low $\mathrm{pH}$, whereas the $\operatorname{Reg} A / \operatorname{Reg} B$ and $\operatorname{Prr} A / \operatorname{Pr} B$ systems in the photosynthetic bacteria appear to respond to decreases in $\mathrm{O}_{2}$ concentration to switch on genes for photosynthetic activity (Mosley et al., 1994; Eraso \& Kaplan, 1995). An important question is why such similar proteins should have such apparently different functions in the two organisms. One obvious answer to the paradox is that despite their overall similarity their differences are great enough to allow one to sense and respond to $\mathrm{O}_{2}$ and the other to react to low $\mathrm{pH}$. In the photosynthetic bacteria, a connection between falling $\mathrm{pO}_{2}$ and $\mathrm{pH}$ is not obvious, so that this system being only responsive to $\mathrm{pO}_{2}$ raises no problems. However, the two conditions - low $\mathrm{pO}_{2}$ and low $\mathrm{pH}$ - may well be physiologically linked for heterotrophic bacteria like $R$. meliloti; fermentative metabolism at high cell density and low $\mathrm{pO}_{2}$ will produce acidic end-products and a low $\mathrm{pH}$. A response to low $\mathrm{pO}_{2}$ which anticipated a fall in $\mathrm{pH}$ would be biologically sensible for R. meliloti. Another important, though not easy question to answer would then be whether the same sensorregulator system can detect and respond to both environmental signals, or whether such a system might perhaps respond to some parameter influenced by both. The simplest situation, however, is still that the $\mathrm{RegB} / \operatorname{RegA}$ and $\operatorname{Pr} \mathrm{B} / \operatorname{Prr} \mathrm{A}$ sytstems react to $\mathrm{O}_{2}$ concentration and the ActS/ActR system to low $\mathrm{pH}$.

Low $\mathrm{pH}$ induces synthesis of proteins not normally produced at neutral $\mathrm{pH}$ in enteric bacteria (Aliabadi et al., 1988; Olson, 1993) and root nodule bacteria (Glenn et al., 1986; Aarons \& Graham, 1991). How the actS/actR sensor-regulator system may control expression of genes involved in resistance to low $\mathrm{pH}$ remains to be determined. Identification of genes which are regulated by the act $/$ act $\mathrm{R}$ system is in progress.

\section{ACKNOWLEDGEMENTS}

This work was generously supported by the Wool Research Corporation and the Australian Research Council. W.G.R. gratefully acknowledges receipt of a Wool Research Corporation studentship.

\section{REFERENCES}

Aarons, S. R. \& Graham, P.H. (1991). Response of Rhizobium leguminosarum biovar phaseoli to acidity. Plant Soil 134, 145-151.

Albright, L. M., Huala, E. \& Ausubel, F. (1989). Prokaryotic signal transduction mediated by sensor and regulator pairs. Annu Rev Genet 23, 311-336.

Aliabadi, Z., Park, Y. K., Slonczewski, J. L. \& Foster, J. W. (1988). Novel regulatory loci controlling oxygen- and $\mathrm{pH}$-regulated gene expression in Salmonella typhimurium. J Bacteriol 170, 842-851.

Booth, I. R. (1985). Regulation of cytoplasmic $\mathrm{pH}$ in bacteria. Microbiol Rev 49, 359-378.

Bourret, R. B., Borkovich, K. A. \& Simon, M. I. (1991). Signal transduction involving protein phosphorylation in prokaryotes. Annu Rev Biochem 60, 401-441.

Boyd, J. M., Koga, T. \& Lory, S. (1994). Identification and characterization of pils, an essential regulator of pilin expression in Pseudomonas aeruginosa. Mol Gen Genet 243, 565-574.

Boyer, H. W. \& Roulland-Dussoix, D. (1969). A complementation analysis of the restriction and modification of DNA in Escherichia coli. J Mol Biol 41, 459-472.

Caldwell, P. C. (1956). Intracellular pH. Int Rev Cytol 5, 229-277.

Chen, C. \& Winans, S. C. (1991). Controlled expression of the transcriptional activator gene virG in Agrobacterium tumefaciens by using the Escherichia coli lac promoter. J Bacteriol 173, 1139-1144.

Ditta, G., Stanfield, S., Corbin, D. \& Helinski, D. R. (1980). Broad host range DNA cloning system for Gram-negative bacteria: construction of a gene bank of Rhizobium meliloti. Proc Natl Acad Sci US A 77, 7347-7351.

Eraso, J. M. \& Kaplan, S. (1994). PrrA, a putative response regulator involved in oxygen regulation of photosynthesis gene expression in Rhodobacter sphaeroides. J Bacteriol 176, 32-43.

Eraso, J. M. \& Kaplan, S. (1995). Oxygen-insensitive synthesis of the photosynthetic membranes of Rhodobacter sphaeroides - a mutant histidine kinase. J Bacteriol 177, 2695-2706.

Fellay, R., Frey, J. \& Krisch, H. (1987). Interposon mutagenesis of soil and water bacteria : a family of DNA fragments designed for invitro insertional mutagenesis of Gram-negative bacteria. Gene 52, 147-154.

Foster, J. W. (1992). The acid-tolerance response of Salmonella typhimurium involves transient synthesis of key acid shock proteins. $J$ Bacteriol 175, 1981-1987.

Foster, J. W. \& Hall, H. K. (1990). Adaptive acidification tolerance response of Salmonella typhimurium. J Bacteriol 172, 771-778.

Foster, J. W. \& Hall, H. K. (1991). Inducible $\mathrm{pH}$ homeostasis and the acid-tolerance response of Salmonella typhimurium. J Bacteriol 173, 5129-5135.

Foster, J. W., Park, Y. K., Bang, I. S., Karem, K., Betts, H., Hall, H. K. \& Shaw, E. (1994). Regulatory circuits involved with $\mathrm{pH}$ regulated gene expression in Salmonella typbimurium. Microbiology 140, 341-352.

Glenn, A. R. \& Dilworth, M. J. (1994). The life of root nodule bacteria in the acidic underground. FEMS Microbiol Lett 123, 1-9.

Glenn, A. R., Knuckey, R. \& Dilworth, M. J. (1986). Periplasmic proteins of Rhizobium: variation with growth conditions and the use in strain identification. FEMS Microbiol Lett 70, 842-851.

Goodson, N. Y. \& Rowbury, R. J. (1989a). Resistance of acidhabituated Escherichia coli to organic acids and its medical and applied significance. Lett Appl Microbiol 8, 211-214. 
Goodson, N. Y. \& Rowbury, R. J. (1989b). Habituation to normally lethal acidity by prior growth of Escherichia coli at a sub-lethal acid $\mathrm{pH}$ value. Lett Appl Microbiol 8, 77-79.

Goss, T. G., O'Hara, G. W., Dilworth, M. J. \& Glenn, A. R. (1990). Cloning, characterisation, and complementation of lesions causing acid-sensitivity in $\mathrm{Tn} 5$ induced mutants of Rbizobium meliloti WSM419. J Bacteriol 172, 5173-5179.

Graham, P. H. \& Parker, C. A. (1964). Diagnostic features in the characterisation of the root-nodule bacteria of legumes. Plant Soil 20, 383-396.

Howieson, J. G. \& Ewing, M. A. (1986). Acid-tolerance in the Rbizobium meliloti-Medicago symbiosis. Aust J Agric Res 37, 55-64.

Ishimoto, K. S. \& Lory, S. (1992). Identification of pilR, which encodes a transcriptional activator of the Pseudomonas aeruginosa pilin gene. J Bacteriol 174, 3514-3521.

Kaminski, P. A. \& Elmerich, C. (1991). Involvement of FixLJ in the regulation of nitrogen fixation in Azorbizobium caulinodans. Mol Microbiol 5, 665-673.

Karem, K. L., Foster, J. W. \& Bej, A. K. (1994). Adaptive acid tolerance response (ATR) in Aeromonas bydropbila. Microbiology 140, 1731-1736.

Lee, I. S., Slomczewski, J. L. \& Foster, J. W. (1994). A low-pHinducible, stationary-phase acid tolerance response in Salmonella typhimurium. J Bacteriol 176, 1422-1426.

Lijestroem, P., Laamanen, I. \& Palva, E. T. (1988). Structure and the expression of the $0 m p \mathrm{~B}$ operon, the regulatory locus of the outer membrane porin regulon in Salmonella typhimurium LT-2. J Mol Biol 201, 663-673.

Miller, J. H. (1972). Experiments in Molecular Genetics. Cold Spring Harbor, NY: Cold Spring Harbor Laboratory.

Monson, E. K., Ditta, G. S. \& Helinski, D. R. (1995). The oxygen sensor protein, FixL, of Rbizobium meliloti-role of histidine residues in heme binding, phosphorylation, and signal transduction. $J$ Biol Chem 270, 5243-5250.

Mosley, C. S., Suzuki, J. Y. \& Bauer, C. E. (1994). Identification and molecular genetic characterization of a sensor kinase responsible for coordinately regulating light harvesting and reaction center gene expression in response to anaerobiosis. $J$ Bacteriol 176, 7566-7573.

Munns, D. N. (1986). Acid soil tolerance in legumes and rhizobia. In Advances in Plant Nutrition, pp. 63-90. Edited by B. Tinker \& A. Lauchlie. New York: Praeger Scientific.

O'Hara, G. W. \& Glenn, A. R. (1994). The adaptive acid tolerance response in root-nodule bacteria and Escherichia coli. Arch Microbiol 161, 286-292.

O'Hara, G. W., Goss, T. J., Dilworth, M. J. \& Glenn, A. R. (1989). Maintenance of intracellular $\mathrm{pH}$ and acid tolerance in Rhizobium meliloti. Appl Environ Microbiol 55, 1870-1876.

Nara, F., Matsuyama, S., Mizuno, T. \& Mizushima, S. (1986). Molecular analysis of mutant $o m p R$ genes exhibiting different phenotypes as to osmoregulation of the $o m p F$ and $o m p C$ genes of Escherichia coli. Mol Gen Genet 202, 194-199.

Olson, E. R. (1993). Influence of $\mathrm{pH}$ on bacterial gene expression. Mol Microbiol 8, 5-14.

Padan, E. \& Schuldiner, S. (1986). Intracellular $\mathrm{pH}$ regulation in bacterial cells. Methods Enzymol 125, 337-365.

Padan, E., Zilberstein, D. \& Schuldiner, S. (1982). pH homeostasis in bacteria. Biocbim Biophys Acta 650, 151-166.

Parkinson, J. S. \& Kofoid, E. C. (1992). Communication modules in bacterial signalling proteins. Annu Rev Genet 26, 71-112.
Pearson, W. R. \& Lipman, D. J. (1988). Improved tools for biological sequence analysis. Proc Natl Acad Sci USA 85, 2444-2448.

Penny, D. C., Nyborg, M., Hoyt, P. B., Rice, W. A., Siemens, B. \& Laverty, D. H. (1977). An assessment of the soil acidity problem in Alberta and Northeastern British Columbia. Can J Soil Sci 57, 157-164.

Phillips-Jones, M. K. \& Hunter, C. N. (1994). Cloning and nucleotide sequence of regA, a putative response regulator gene of Rhodobacter sphaeroides. FEMS Microbiol Lett 116, 269-275.

Qian, Y. L. \& Tabita, F. R. (1996). A global signal transduction system regulates aerobic and anaerobic $\mathrm{CO}_{2}$ fixation in Rhodobacter sphaeroides. J Bacteriol 178, 12-18.

Quandt, J. \& Hynes, M. F. (1993). Versatile suicide vectors which allow direct selection for gene replacement in Gram-negative bacteria. Gene 127, 15-21.

Raja, N., Goodson, M., Chui, W. C. M., Smith, D. G. \& Rowbury, R. J. (1991a). Habituation to acid in Eschericbia coli: conditions for habituation and its effects on plasmid transfer. J Appl Bacteriol 70, 59-65.

Raja, N., Goodson, M., Smith, D. G. \& Rowbury, R. J. (1991b). Decreased DNA damage by acid and increased repair of aciddamaged DNA in acid habituated Escherichia coli. J Appl Bacteriol 70, 507-511.

Reeve, W. G., Tiwari, R. P., Dilworth, M. J. \& Glenn, A. R. (1993). Calcium affects the growth and survival of Rbizobium meliloti. Soil Biol Biochem 25, 581-586.

Robson, A. D. \& Loneragan, J. F. (1970). Nodulation and growth of Medicago truncatula on acid soils. II. Colonization of acid soils by Rbizobium meliloti. Aust J Agric Res 21, 435-445.

Sambrook, J., Fritsch, E. F. \& Maniatis, T. (1989). Molecular Cloning: a Laboratory Manual, 2nd edn. Cold Spring Harbor, NY: Cold Spring Harbor Laboratory.

Sganga, M. W. \& Bauer, C. E. (1992). Regulatory factors controlling photosynthetic reaction centre and light-harvesting gene expression in Rbodobacter capsulatus. Cell 68, 945-954.

Spaink, H. P., Robert, G. H., Okker, C. A., Wijffelman, E. P. \& Ben, J. J. L. (1987). Promoters in the nodulation region of the Rhizobium leguminosarum sym plasmid pRL1 J1. Plant Mol Biol 9, 27-39.

Sprent, J. I. (1990). Evolution, structure and function of nitrogenfixing root nodules: confession of ignorance. In Nitrogen Fixation: Achievements and Objectives, pp. 45-54. Edited by P. M. Gresshoff, L. E. Roth, J. Stacey \& W. A. Newtons. New York: Chapman \& Hall.

Stock, J. B., Ninfa, A. J. \& Stock, A. M. (1989). Protein phosphorylation and regulation of adaptive responses in bacteria. Microbiol Rev 53, 450-490.

Tate, S., Kato, M., Nishimura, Y., Arata, Y. \& Mizuno, T. (1988). Location of DNA-binding segment of a positive regulator, OmpR, involved in activation of the $o m p F$ and $o m p C$ genes of Escherichia coli. FEBS Lett 242, 27-30.

Thomas, J. A., Cole, R. E. \& Langworthy, T. A. (1976). Intracellular $\mathrm{pH}$ measurements with a spectroscopic probe generated in situ. Fed Proc 35, 1455.

Thompson, J. D., Higgins, D. G. \& Gibson, T. J. (1994). Clustal w : improving the sensitivity of progressive multiple sequence alignment through sequence weighting, position-specific gap penalties and weight matrix choice. Nucleic Acids Res 22, 4673-4680.

Tiwari, R. P., Reeve, W. G. \& Glenn, A. R. (1992). Mutations conferring acid-sensitivity in the acid-tolerant strains of Rbizobium 
meliloti WSM419 and Rhizobium leguminosarum biovar viciae WSM710. FEMS Microbiol Lett 100, 107-112.

Tiwari, R. P., Reeve, W. G., Dilworth, M. J. \& Glenn, A. R. (1996). An essential role for act $A$ in acid tolerance of Rbizobium meliloti. Microbiology 142, 601-610.

Waddel, W. J. \& Bates, R. G. (1969). Intracellular pH. Pbysiol Rev 49, 285-329.

Wanner, B. L. (1992). Is cross regulation by phosphorylation of two-component response regulator proteins important in bacteria? J Bacteriol 174, 2053-2058.
Yanisch-Perron, C., Vieira, J. \& Messing, J. (1985). Improved M13 cloning vectors and host strains: nucleotide sequences of the M13mp18 and pUC19 vectors. Gene 33, 103-119.

Young, J. P. W., Downer, H. L. \& Eardly, B. D. (1991). Phylogeny of the phototrophic Rhizobium strain BTAil by polymerase chain reaction-based sequencing of a $16 \mathrm{~S}$ rRNA gene segment. $J$ Bacteriol 173, 2271-2277.

Received 15 November 1995; revised 13 February 1996; accepted 23 February 1996. 